\title{
Rancang Bangun Penjualan Tiket Online Lokawisata Baturraden Berbasis Website
}

\author{
Hekal Ramadhan \\ Universitas Amikom Purwokerto, Purwanegara, Purwokerto dan 53127, Indonesia \\ hekalramadhan170198@gmail.com
}

Abstrak

Di Jaman teknologi komputerisasi sekarang ini, dengan semakin banyaknya masyarakat pengguna komputer yang memanfaatkan berbagai aplikasi untuk memudahkan aktivitas masyarakat untuk memenuhi kebutuhan mereka sehari-hari, mereka cenderung memillih sesuatu yang instan, aman dan efisien tidak terkecuali dalam hal jual-beli. Tidak hanya dalam membeli barang, tetapi ketika hendak berpergian \& malas untuk antri pembelian tiket, sekarang sangatlah mudah karena adanya website penjualan tiket wisata secara online. Seperti pada website penjualan tiket online lokawisata baturraden ini sangat mempermudah bagi pengunjung lokawisata untuk membeli tiketnya tanpa mengantri di tempat wisata tersebut. Mengacu pada penjualan tiket online tersebut maka untuk membantu tercapainya target penjualan di website tiket online lokawisata tersebut, maka penulis merancang dan membangun sebuah sistem informasi website tiket online lokawisata baturraden berbasis website dengan bahasa pemrograman PHP yang dibuat pada komputer dengan sistem operasi Windows dengan menggunakan aplikasi editor "Notepad++". Alasan memakai Notepad++ karena aplikasi ini dapat didownload secara gratis dan memiliki aturan-aturan yang mudah dipahami.

Kata Kunci: PHP, MySQL, E-Ticketing, Tiket Online, Tiket Online Wisata

\section{Pendahuluan}

\subsection{Latar Belakang Masalah}

Negara Republik Indonesia merupakan Negara yang memiliki potensi sumber daya alam yang berlimpah, keanekaragaman hayati dan peninggalan sejarah/budaya. Berlimpahnya sumber daya alam yang ada dapat meningkatkan pertumbuhan ekonomi ketika sumber daya tersebut dapat di kelola dengan baik sesuai dengan apa yang paling diminati masyarakat sehingga pemanfaatan sumber daya alam tersebut tidak akan menghabiskan waktu ataupun materi akibat ketidakberhasilan dalam mengelola suatu sumber daya.

Pariwisata merupakan salah satu pemanfaatan sumber daya alam yang dapat bernilai ekonomi tinggi bagi suatu daerah yang mengelola sumber daya alam menjadi suatu tempat wisata yang dapat menarik pengunjung baik dari dalam maupun dari luar negeri, disamping bernilai ekonomi yang tinggi, pariwisata dapat menumbuhkan dan meningkatkan rasa bangga terhadap bangsa sehingga akan tumbuh masyarakat yang lebih peduli terhadap suatu bangsa. Pariwisata merupakan hal yang diminati oleh setiap individu, karena dapat menghilangkan kejenuhan, berkembangnya kreativitas dan mampu menunjang produktivitas suatu individu.

Dasar hukum pengembangan pariwisata yang sesuai dengan prinsip pengembangan adalah Undang-Undang RI Nomor 10 Tahun 2009 Tentang Kepariwisataan yang tertulis pada pasal 6 yang berbunyi Pembangunan kepariwisataan dilakukan berdasarkan asas sebagaimana dimaksud dalam Pasal 2 yang diwujudkan melalui pelaksanaan memperhatikan keanekaragaman, keunikan, dan kekhasan budaya dan alam, serta kebutuhan manusia untuk berwisata. 
Era globalisasi sekarang, bidang pariwisata merupakan salah satu kegiatan yang mempunyai peranan yang sangat strategis dalam menunjang pembangunan perekonomian nasional. Sektor ini dicanangkan selain sebagai salah satu sumber penghasil devisa yang cukup andal, juga merupakan sektor yang mampu menyerap tenaga kerja dan mendorong perkembangan investasi. Untuk mengembangkan sektor ini pemerintah berusaha keras membuat rencana dan berbagai kebijakan yang mendukung kearah kemajuan sektor ini. Salah satu kebijakan tersebut adalah menggali, menginventarisir dan mengembangkan obyek-obyek wisata yang ada sebagai daya tarik utama bagi wisatawan.

\subsection{Rumusan Masalah}

Rumusan masalah yang dapat disusun berdasarkan pemaparan diatas adalah bagaimana cara membangun sistem penjualan tiket berbasis website menggunakan laravel?

\subsection{Batasan Penelitian}

Adapun yang menjadi batasan penelitian adalah :

- Website ini untuk pembelian tiket masuk lokawisata Baturraden dan tidak menjual tiket wahana non tiketing.

- Website ini bisa untuk memesan tiket secara online dan akan menampilkan bukti pembayaran yang akan menampilkan kode untuk diberikan kepada petugas pintu masuk lokawisata.

\subsection{Tujuan Penelitian}

- Tujuan dari penelitian ini adalah untuk mengembangkan sebuah website penjualan tiket lokawisata berbasis website sebagai media penjualan tiket untuk mempermudah proses penjualan dan efisiensi dalam pemesanan serta pembayaran dan mempermudah para wisatawan dalam membeli tiket wisata secara online dan tidak mengantri di loket pembelian tiket wisata.

\section{Kajian Pustaka}

\subsection{Landasan Teori}

\section{Sistem Informasi Penjualan}

Sistem adalah suatu kesatuan yang terdiri dari komponen atau elemen yang dihubungkan bersama untuk memudahkan aliran informasi, materi, atau energi. Informasi merupakan hasil pengolahan dari sebuah model, organisasi, ataupun suatu perubahan bentuk dari data yang memiliki nilai tertentu,dan bisa digunakan untuk menambah pengetahuan bagi yang menerimanya. Dalam hal ini, data bisa dianggap sebagai obyek dan informasi adalah suatu subyek yang bermanfaat bagi penerimanya. Informasi juga bisa disebut sebagai hasil pengolahan atau pemrosesan data. (Nugroho, 2011).

\section{Website}

Website merupakan suatu halaman yang menyajikan berbagai informasi yang menggunakan konsep hyperlink (tautan) yang memudahkan bagi para surfer (para pemakai komputer yang melakukan penelusuran informasi melalui internet). Website menyajikan berbagai macam informasi yang disajikan dalam bentuk multimedia seperti teks, animasi, suara, video.

\section{Framework Laravel}

Framework Laravel adalah kerangka kerja web PHP gratis, open-source, dibuat oleh Taylor Otwell dan ditujukan untuk pengembangan aplikasi web mengikuti pola arsitektur model-viewcontroller (MVC) dan berdasarkan Symfony. Beberapa fitur Laravel adalah sistem pengemasan modular dengan manajer ketergantungan khusus, berbagai cara untuk mengakses basis data relasional, utilitas yang membantu dalam penerapan dan pemeliharaan aplikasi, dan orientasinya terhadap gula sintaksis. Situs resmi Laravel : https://laravel.com.

Laravel adalah sebuah Framework PHP dirilis dibawah lisensi MIT dengan kode sumber yang sudah disediakan oleh Github, sama seperti framework-framework yang lain, Laravel dibangun dengan konsep MVC (Model-Controller-View), kemudian Laravel dilengkapi juga command line 
tool yang bernama "Artisan" yang bisa digunakan untuk packaging bundle dan instalasi bundle melalui command prompt[1].

Framework secara sederhana dapat diartikan kumpulan dari fungsi-fungsi/prosedur-prosedur dan class-class untuk tujuan tertentu yang sudah siap digunakan sehingga bisa lebih mempermudah dan mempercepat pekerjaan seorang pemrograman, tanpa harus membuat fungsi atau class dari awal.

\section{Pengertian RDBMS (Relational Database Management System)}

RDBMS (Relational Database Management System) adalah program yang memungkinkan pengguna database untuk membuat, mengelola, dan menggunakan data pada suatu model relational. Dengan demikian, tabel-tabel yang ada pada database memiliki relasi antara satu tabel dengan tabel lainny [2].

RDBMS merupakan suatu penyusunan data yang terstruktur yang disimpan dalam media pengingat (harddisk) yang tujuanya adalah agar data tersebut dapat diakses dengan mudah dan cepat [3].

\section{Pengertian Tiket Online}

Tiket Online atau E-ticketing adalah suatu cara untuk mendokumentasikan proses penjualan dari aktifitas perjalanan pelanggan tanpa harus mengeluarkan dokumen berharga secara fisik atau paper ticket [4].

Sedangkan E-Ticketing adalah sebuah metode perdagangan, pembelian, dan penjualan tiket dari berbagai produk jasa khususnya jasa perjalanan melalui media internet dan komputer [5].

\section{Metode Penelitian}

\subsection{Metode Pengumpulan Data}

Metode pengumpulan data yang digunakan penulis dalam penyusunan penelitian yaitu :

- Observasi

Observasi merupakan salah satu teknik pengumpulan data yang cukup efektif untuk mempelajari suatu sistem. Observasi adalah pengamatan langsung terhadap suatu kegiatan yang sedang dilakukan. Pada waktu melakukan observasi, peneliti dapat ikut juga berpartisipasi atau hanya mengamati saja orang-orang yang sedang melakukan suatu kegiatan tertentu yang diobservasi.

Pada penelitian ini observasi yang dilakukan yaitu mendatangi UPT Baturraden di desa Karangmangu untuk mengetahui dan mengamati langsung keadaan yang ada disana dan melakukan tanya jawab dengan pihak lokawisata Baturraden.

\section{- Wawancara}

Wawancara telah diakui sebagai teknik pengumpulan data yang penting dan banyak dilakukan dalam pengembangan pencarian informasi. Wawancara memungkinkan pewawancara untuk mengumpulkan data secara bertatap muka langsung dengan orang yang diwawancarai.

Pada penelitian ini wawancara yang dilakukan penulis melakukan tanya jawab langsung dengan narasumber atau dengan kepala tata usaha di UPT Baturraden yaitu Bapak Samingin agar didapatkan data mengenai dan mengetahui permasalahan apa yang ada disana serta mencari solusi untuk mengatasinya.

\section{- Studi Kepustakaan}

Studi kepustakaan menurut studi kepustakaan adalah teknik pengumpulan data dengan cara mengumpulkan, membaca, dan memahami berbagai buku yang berkaitan dengan yang dibutuhkan agar dapat dipadukan antara permasalahan dengan teknik yang tepat sehingga diharapkan mampu memecahkan permasalahan yang timbul.

Penelitian yang saya lakukan yaitu mengunjungi lokasi lokawisata Baturraden, melihat wisatawisata yang ada di dalam objek wisata Baturraden, dan melakukan observasi dan wawancara dengan 
pihak lokawisata Baturraden. Data yang diambil dari penelitian ini yaitu data pendapatan dan jumlah pengunjung lokawisata Baturraden pada 5 tahun terakhir.

\section{- Dokumentasi}

Dokumentasi adalah suatu cara yang digunakan untuk memperoleh data dan informasi dalam bentuk buku, arsip, dokumen, tulisan angka dan gambar yang berupa laporan serta keterangan yang dapat mendukung penelitian. Dokumentasi digunakan untuk mengumpulkan data kemudian ditelah. Dokumentasi yang digunakan dalam penelitian ini meliputi foto beberapa wisata dan foto bersama narasumber [6].

\subsection{Konsep Penelitian}

Guna menyelesaikan penelitian maka dibuat konsep penelitian yang digambarkan pada kerangka penelitian sebagai berikut :

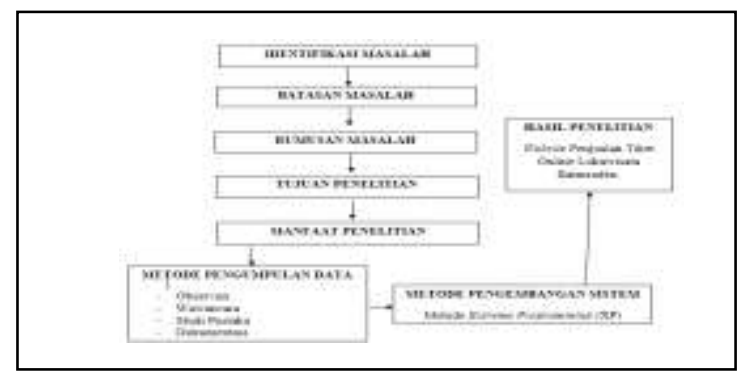

Gambar 1. Kerangka Penelitian

Adapun penjelasan setiap tahapan kerangka penelitian yang ada pada Gambar 1 adalah sebagai berikut :

\section{Identifikasi Masalah}

Merupakan langkah awal yang dilakukan untuk mempelajari tentang kasus atau tema yang diangkat oleh peneliti, identifikasi masalah yang dilakukan peneliti sebagai berikut :

\section{1) Menentukan Batasan Masalah}

Pada tahap ini peneliti menentukan batasan masalah, yaitu penelitian ini membahas tentang bagaimana merancang dan membangun sebuah website tiket online untuk penjualan tiket masuk lokawisata, website ini hanya sebagai alat bantu untuk menghubungkan antara wisatawan dan pihak lokawisata Baturraden, serta menggunakan bahasa pemrograman laravel.

\section{2) Menentukan Rumusan Masalah}

Pada tahap ini peneliti menentukan rumusan masalah, yaitu bagaimana merancang dan membangun (membuat) website tiket online wisata berbasis laravel?

\section{3) Menentukan Tujuan Penelitian}

Pada tahap ini dibuat sebuah tujuan penelitian, yaitu merancang dan membangun sebuah Website penjualan tiket wisata secara online menggunakan laravel yang diharapkan dapat mempermudah wisatawan dan pihak lokawisata Baturraden dalam penjualan dan pembelian tiket masuk wisata.

Alasan memilih untuk menggunakan framework laravel adalah laravel yang bersifat open source, karena laravel bersifat open source maka akan mendukung proses development yang dilakukan. Selain itu laravel juga mempermudah proses pengembangan website dengan bantuan beberapa fitur unggulan seperti Template Engine, Routing, Modularity.

4) Menentukan Manfaat Penelitian

Tahap selanjutnya peneliti menentukan manfaat penelitian secara teoritis dan aplikatif dari penelitian yang dilakukan.

\section{Metode Pengumpulan Data}


Metode pengumpulan data merupakan cara untuk mengumpulkan data maupun informasi yang diperlukan. Dalam penelitian ini metode pengumpulan data yang digunakan yaitu observasi, wawancara, studi kepustakaan dan dokumentasi.

Dari hasil wawancara dengan narasumber, ada beberapa data yang didapat yaitu data pendapatan dan jumlah pengunjung 5 tahun terakhir, harga tiket masuk wisata, banyaknya wahana pada lokawisata baturraden (ticketing/non ticketing).

\section{Metode Pengembangan Sistem}

Pada penelitian ini metode pengembangan sistem yang digunakan yaitu menggunakan metode pengembangan Extreme Programming (XP) merupakan salah satu metode yang tergolong kedalam Agile Methodologi, yang terdiri dari empat tahapan yaitu planning, design, coding, test.

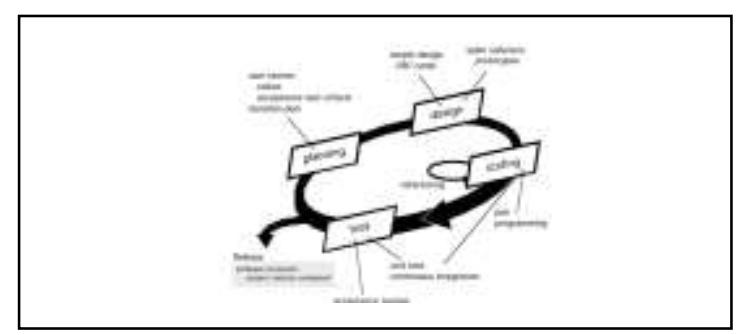

Gambar 2. Metode Pengembangan Sistem [7]

Dalam perancangan dan membangun website, peneliti memiliki beberapa tahapan pengembangan sistem. Berikut adalah uraian tahapan-tahapan dari extreme programming sebagai berikut :

\section{Perencanaan (Planning)}

Planning atau perencanaan adalah proses metode yang dirancang untuk mencapai tujuan tertentu. Perencanaan dimulai dengan memungkinkan developer dari XP untuk memahami output yang dibutuhkan dan fitur-fitur serta fungsionalitas, Developer kemudian menilai alur dari setiap sistem yang dikembangkan.

\section{Pengkodean}

Tahap selanjutnya adalah pengkodean, dalam sistem ini dibangun pengkodeanya menggunakan framework Codeigniter dengan menerapkan konsep MVC (Model View Controller). Pengolahan data menggunakan MySQL.

\section{Desain (Design)}

Tahap ini menekankan pada desain aplikasi secara sederhana. Dalam tahap mendesain alur sistem seperti yang diinginkan maka dalam pengembanganya menggunakan UML (Unified Modelling Language) sebagai alat permodelan untuk membangun perangkat lunak yang akan terjadi sehingga membentuk sistem yang sesuai kebutuhan sistem aplikasi.

\section{Pengujian (Testing)}

Tahapan dilaksanakan dengan tujuan mengetahui bahwa fitur-fitur sistem yang ada telah berfungsi dengan baik. Dalam tahap pengujian ini penulis menggunakan metode alpha testing dan beta testing. Pengujian ini dilakukan agar mengetahui bagaimana respon dari setiap menu navigasi apakah sudah berjalan sesuai yang diharapkan dan fokus pada fitur dan fungsionalitas sistem secara keseluruhan. Pengujian dilakukan dengan menjalankan proses-proses yang ada dalam sistem dengan memasukan data sesuai kebutuhan.

\section{Hasil dan Pembahasan}

\subsection{Analisis Sistem}

Website Penjualan Tiket Lokawisata Baturraden ini menggunakan metode pengembangan sistem Extreme Programming (XP), dalam metode ini diharapkan dalam merancang bangun website ini bisa sesaui yang diharapkan oleh pengembang dan penggunanya. 
Berikut penjabaran dari empat bagian kegiatan kerangka kerja metode Extreme Programming (XP) :

\section{Perencanaan (Planning)}

Sebelum melakukan pembuatan website, penulis melakukan observasi untuk memperoleh data yang dibutuhkan untuk pembuatan website. Penulis melakukan wawancara kepada Bapak Samingin selaku kepala Tata Usaha (TU) di lokawisata Baturraden, beliau menjelaskan bahwa pada tiap tahunnya pendapatan dan jumlah pengunjung wisata Baturraden terus meningkat sehingga menyebabkan suatu ketika hari libur terkadang mengalami kewalahan karena wisatawan yang berkunjung sangat banyak dan menyebabkan antri pada loket pembelian tiket wisata Baturraden. Hasil observasi dan wawancara penulis gunakan untuk acuan merancang dan membangun sebuah website penjualan tiket online wisata khususnya pada lokawisata Baturraden.

\section{Identifikasi Kebutuhan Pengguna}

Setelah dilakukan observasi dan wawancara dengan kepala tata usaha lokawisata Baturraden, maka ditemukan solusi yang dapat membantu pihak lokawisata baturraden terutama pada penjualan tiket masuk wisatanya.

\section{Menganalisa Kelayakan Sistem}

Dari solusi yang didapatkan berdasarkan kebutuhan pengguna yaitu merancang dan membangun website penjualan tiket online lokawisata Baturraden, maka dilakukan analisis kelayakan sistem bertujuan agar sistem yang dibuat dapat bermanfaat bagi pihak lokawisata Baturraden terutama pada bagian loket penjualan tiket masuk wisata Baturraden dengan mencapai susunan yang sesuai dengan kebutuhan dan kondisi.

\section{Analisis Kelayakan Teknologi}

Secara garis besar, teknologi yang diinginkan adalah teknologi yang mudah dioperasikan baik untuk orangtua maupun anak muda sehingga tepat untuk diterapkan. Pengembang mengutamakan kebutuhan client agar mudah mengoperasikan website yang akan dibuat, sehingga pengguna dengan mudah menggunakan website tersebut.

Teknologi yang akan di pakai pada website ini cukup bagus dan cepat dalam menyelesaikan pekerjaan. Teknologi untuk pembuatan website ini adalah teknologi framework PHP laravel yang diintegrasikan dengan database $M y s q l$.

\section{Analisis Kelayakan Operasi}

Website yang akan diterapkan nanti untuk pengguna, baik pihak wisata, wisatawan ataupun admin tidak memiliki kemampuan khusus sehingga website dapat berjalan dengan benar. Website yang dirancang nantinya akan mudah dioperasikan dan bisa menjadikan solusi pada permasalahan yang telah diuraikan diatas. Website ini harus dilakukan penelitian terlebih dahulu agar memastikan website ini dinyatakan layak untuk dioperasikan. Agar nantinya website ini mudah untuk dioperasikan maka dibuatlah tabel model perancangan.

\section{Perancangan Desain (Design)}

Penulis akan merancang beberapa proses yaitu use case diagram, sequence diagram, activity diagram dan class diagram untuk memudahkan dalam proses sistem penjualan. Penjelasan akan dibahas sebagai berikut :

\section{Use Case Diagram}

Diagram use case ini menggambarkan siapa saja aktor yang terlibat dan fungsi apa saja yang dapat digunakan aktor pada website penjualan tiket online.

a. Identifikasi Aktor

Tabel 1. Identifikasi Aktor

\begin{tabular}{lll}
\hline No & Aktor & Deskripsi \\
\hline
\end{tabular}




\begin{tabular}{ccc}
\hline 1 & Admin & Admin dalam website ini mengelola data pembelian tiket, konfirmasi pembayaran. \\
\hline 2 & Member & Member dalam website ini membeli tiket, konfirmasi pembayaran. \\
\hline
\end{tabular}

\section{b. Use Case Diagram}

Use case diagram sistem yang dikembangkan dapat dilihat pada gambar berikut :

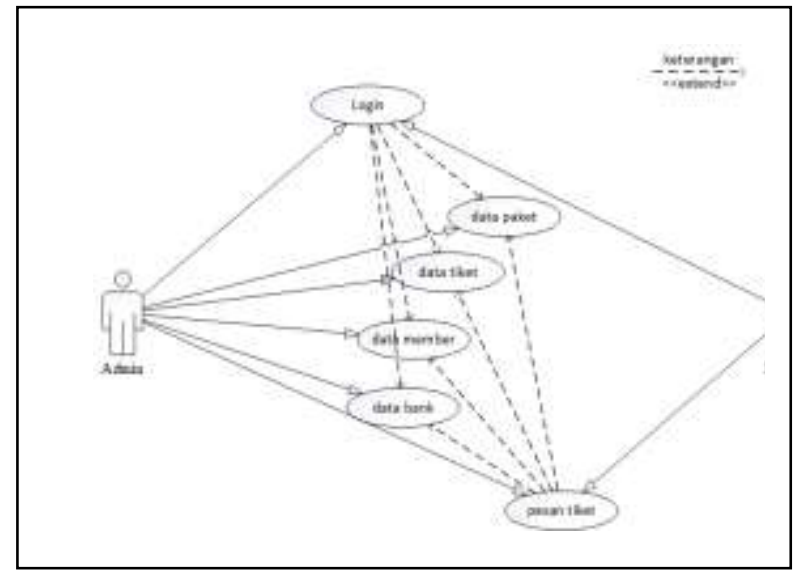

Gambar 3. Use Case Diagram Admin dan Member

\section{Sequence Diagram}

Diagram sequence menggambarkan interaksi pada antar obyek dalam sistem, diagram sequence digunakan untuk menggambarkan skenario pada use case. Berikut adalah diagram sequence website tiket online :

a. Sequence Diagram Login

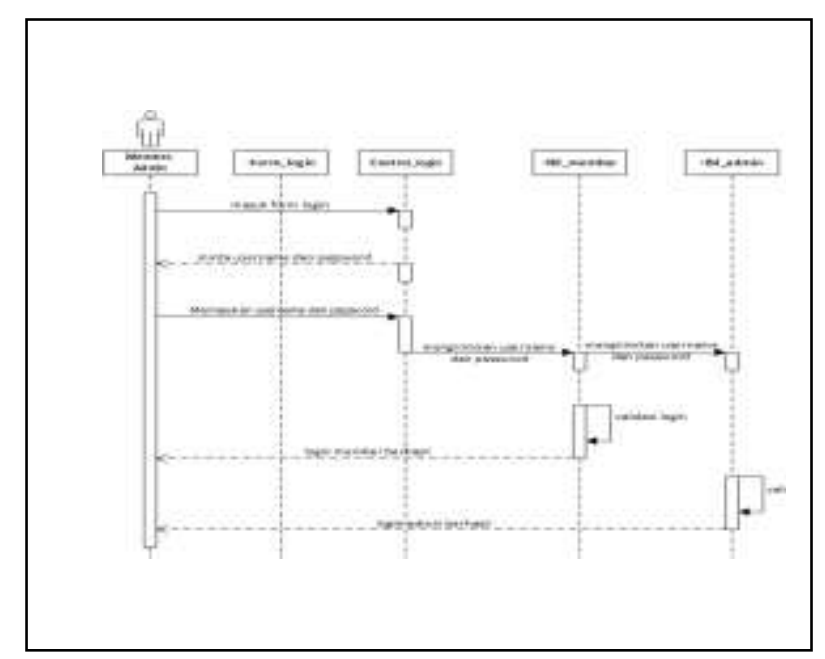

Gambar 4. Sequence Diagram Login

b. Sequence Diagram Daftar 


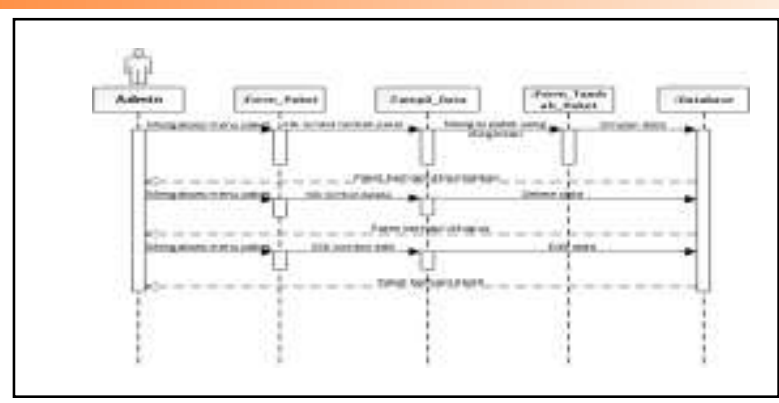

Gambar 5. Sequence Diagram Data Paket

\section{Activity Diagram}

Activity Diagram menggambarkan urutan kegiatan atau urutan aktivitas dari sebuah sistem atau bentuk visual alir kerja untuk menampilkan aktivitas rangkaian kegiatan dalam suatu peristiwa. Berikut activity diagram tiket online :

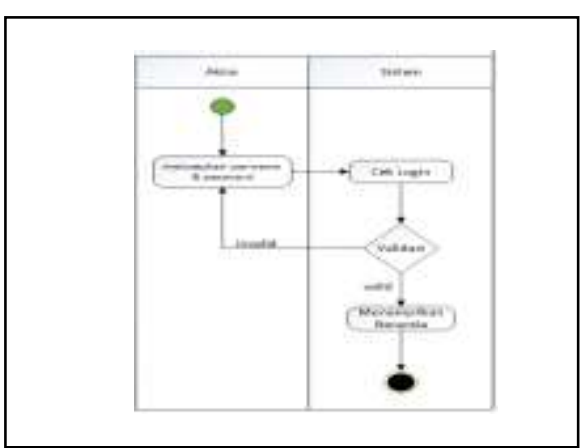

Gambar 6. Activity Diagram Login

4. Class Diagram

Class diagram aplikasi penjualan tiket online berbasis website menggunakan framework laravel

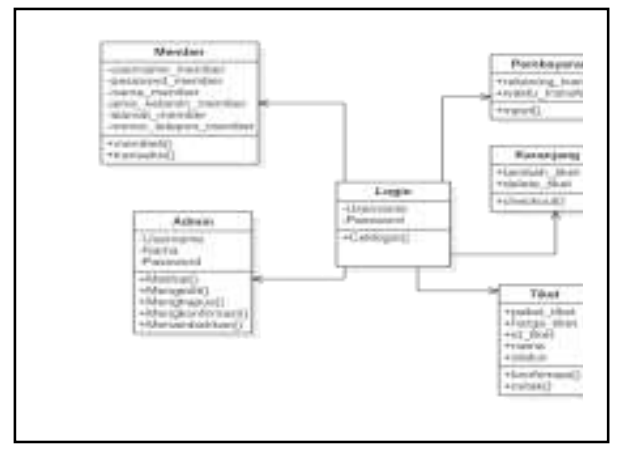

Gambar 7. Class Diagram

5. Perancangan Antarmuka (Interface)

a) Form Login 


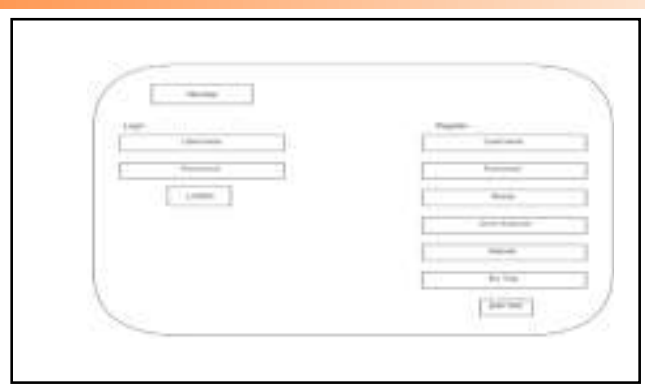

Gambar 8. Form Login dan Daftar Member

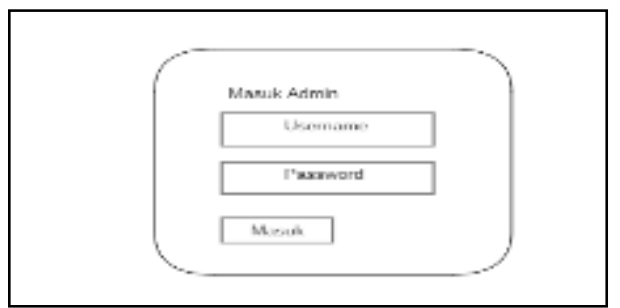

Gambar 9. Form Login Admin

b) Halaman Profil

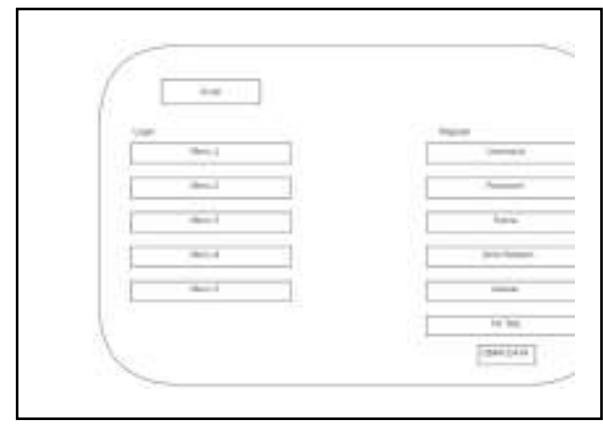

Gambar 10. Halaman Menu Profil Member

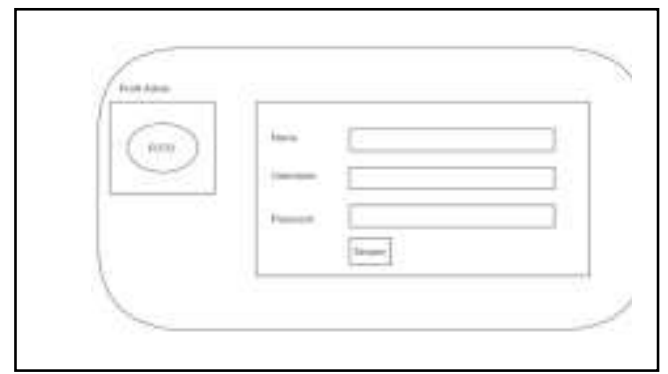

Gambar 11. Halaman Menu Profil Admin

c) Halaman Paket

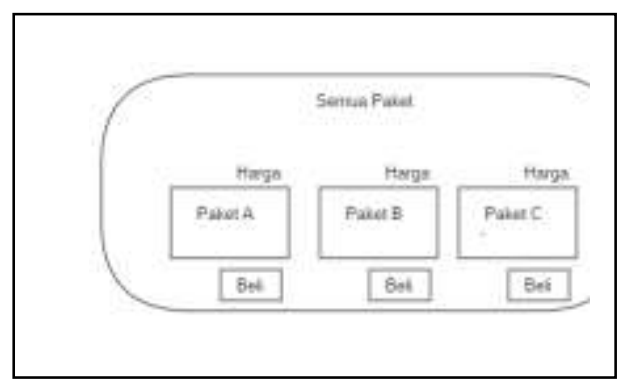

Gambar 12. Halaman Paket 


\section{Pengkodean}

Tahap pengkodean ini merupakan tahap pengembangan website yang merupakan implementasi dari perancangan (design) yang telah dibuat sebelumnya. Pada pembuatan website pada halaman antarmuka dibuat menggunakan HTML, CSS, JavaScript sedangkan fungsionalitas system dan database dibuat menggunakan PHP dan MySQL. Berikut adalah website tiket online lokawisata Baturraden.

1) Pengkodean Website

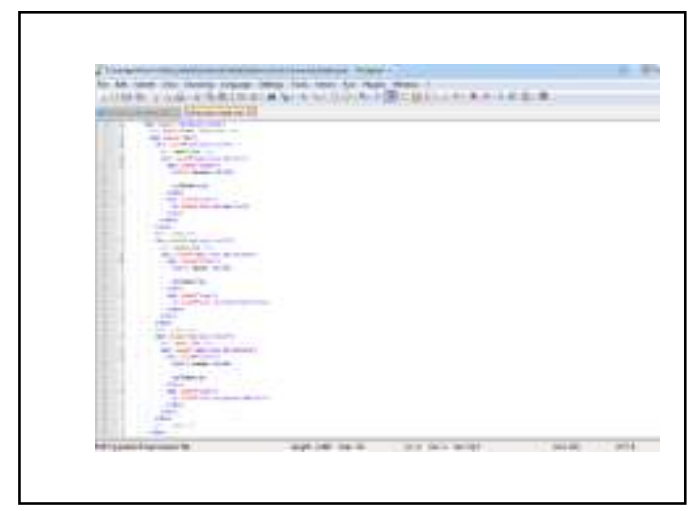

Gambar 13. Kode Tampil Beranda Admin

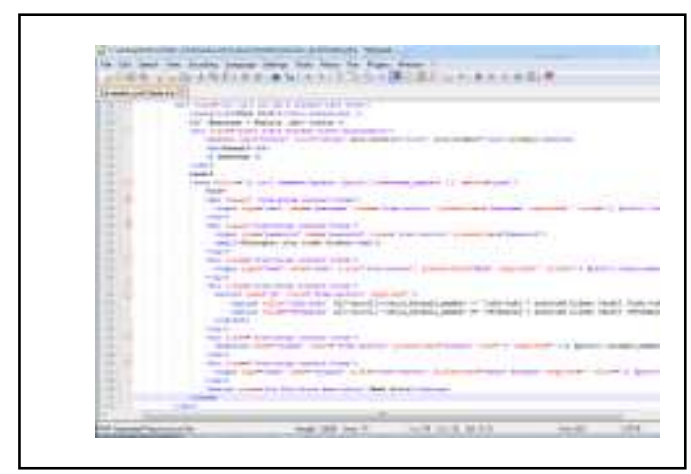

Gambar 14. Kode Ubah Profil Member

\section{2) Implementasi Halaman Antarmuka}

Implementasi halaman antarmuka merupakan sebuah desain yang telah dibuat sebelumnya menjadi bentuk nyata. Berikut adalah hasil implementasi desain halaman antarmuka website penjualan tiket online.

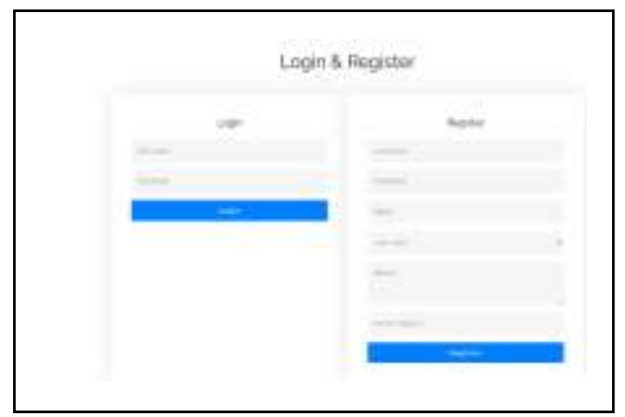

Gambar 15. Halaman Login dan Daftar Member

Gambar 15 merupakan implementasi halaman login. Halaman tersebut akan digunakan oleh member sebagai akses sebelum masuk ke halaman utama. 


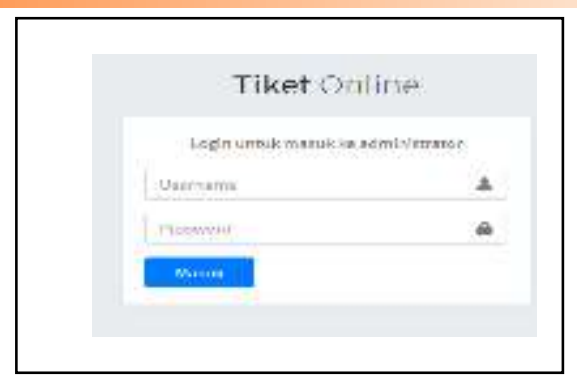

Gambar 16. Halaman Login Admin

Gambar 16 merupakan hasil implementasi halaman login. Halaman tersebut akan digunakan oleh admin untuk hak akses sebelum masuk ke halaman utama.

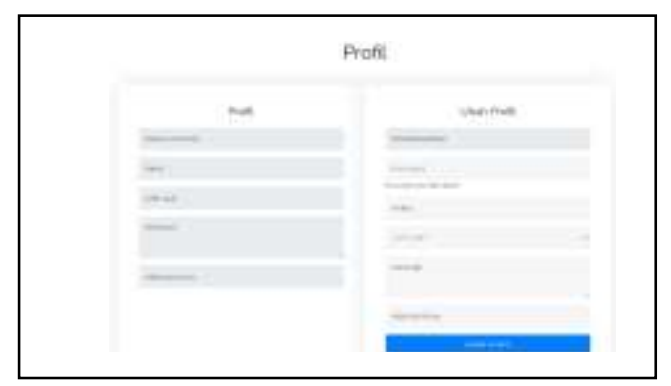

Gambar 17. Halaman Utama Profil Member

Gambar 17 merupakan hasil implementasi halaman utama profil. Halaman tersebut akan digunakan oleh member untuk mengelola data profil.

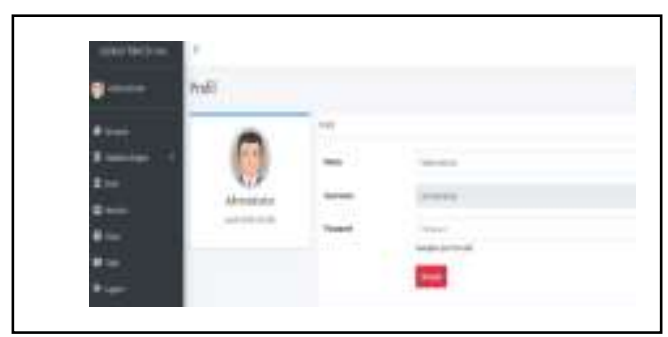

Gambar 18. Halaman Utama Profil Admin

Gambar 18 merupakan hasil implementasi halaman utama profil. Halaman tersebut akan digunakan oleh admin untuk mengelola profil admin.

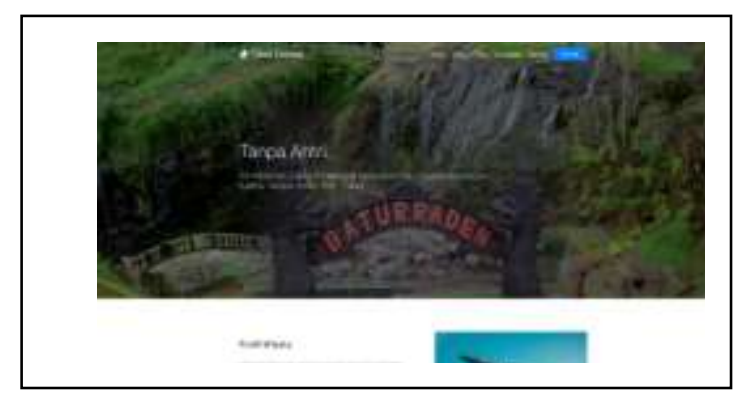

Gambar 19. Halaman Utama Home

Gambar 19 merupakan hasil implementasi halaman utama home. Halaman tersebut akan digunakan oleh semua pengunjung website tersebut untuk mengetahui informasi website dengan lengkap dan jelas. 


\section{Kesimpulan}

Berdasarkan hasil penelitian dan pembahasan yang dipaparkan dapat disimpulkan bahwa website penjualan tiket online lokawisata Baturraden berbasis laravel berhasil dijalankan dengan baik dan semua menu dan fitur yang terdapat pada website tiket online ini berfungsi dengan baik. Pada aplikasi ini member dapat membeli paket tiket wisata dengan metode pembayaran melalui transfer. Pada menu konfirmasi pembayaran terdapat menu untuk menyisipkan bukti pembayaran yang akan dikirim ke admin. Admin dapat mengkonfirmasi pembayaran jika bukti transfer telah masuk. Selain itu admin bisa menambahkan, mengubah ataupun menghapus paket yang tersedia dihalaman paket, admin juga dapat mengedit member ataupun menghapus member yang telah terdaftar.

\section{Ucapan Terima Kasih}

Terimakasih kasih kepada terutaman orang tua saya yang sudah merawat dari kecil membesarkan saya. Kemudian terimakasih kepada dosen-dosen Informatika UNIVERSITAS AMIKOM PURWOKERTO. Dan berterimakasih juga kepada Tim JSTIF yang telah menyempatkan untuk membuat template ini.

\section{Daftar Pustaka}

[1] A. Aminudin, "Cara Efektif Belajar Framework Laravel.” Lokomedia, 2015.

[2] K. M. W. M. Wibowo, I. Kanedi, and J. Jumadi, "Sistem informasi geografis (sig) menentukan lokasi pertambangan batu bara di provinsi bengkulu berbasis website," $J$. Media Infotama, vol. 11, no. 1, 2015.

[3] B. Febriadi and A. Zamsuri, "RDBMS Applications as Online Based Data Archive: A Case of Harbour Medical Center in Pekanbaru," in IOP Conf. Ser. Earth Environ. Sci, 2017, vol. 97, no. 1, pp. 1-5.

[4] G. Ng-Kruelle, P. A. Swatman, J. F. Hampe, and D. S. Rebne, "Biometrics and e-identity (e-passport) in the European Union: end-user perspectives on the adoption of a controversial innovation," J. Theor. Appl. Electron. Commer. Res., vol. 1, no. 2, pp. 12-35, 2006.

[5] B. Nicholas, "Electronic Ticketing: Electronic Business Course," Fribourg, Proj. Pap., 2008.

[6] S. Sugiyono, "Metode penelitian pendidikan pendekatan kuantitatif, dan R\&D," Alf. Bandung, 2015.

[7] R. S. Pressman, “Software Engineering-A Practitioner’s Approach.” McGraw-Hill, 2010. 